\title{
A case of Gitelman syndrome with severe hyponatraemia and hypophosphataemia
}

\author{
Absar Ali ${ }^{1}$, MD, DABIM, Qamar Masood ${ }^{1}$, MD, DABIM, Sonia Yaqub ${ }^{1}$, MBBS, FCPS, Waqar Kashif ${ }^{1}$, MD, DABIM
}

\begin{abstract}
Gitelman syndrome (GS) is a renal tubular disorder of the thiazide-sensitive sodium chloride cotransporter, which is located in the distal tubule of the loop of Henle. We present a rare case of GS complicated by severe hyponatraemia and hypophosphataemia. A 17-year-old boy was admitted to our institution with fever and lethargy. The workup revealed typical features of GS, i.e. hypokalaemia, hypomagnesaemia and metabolic alkalosis. In this report, we discuss the differential diagnoses and rationale for accepting GS as the most likely diagnosis. This case was complicated by severe hyponatraemia $(115 \mathrm{mmol} / \mathrm{L})$ and hypophosphataemia $(0.32 \mathrm{mmol} / \mathrm{L})$. We concluded that the syndrome of inappropriate secretion of antidiuretic hormones could not be ruled out and that respiratory alkalosis was the most likely aetiology of hypophosphataemia. This case report also generates an interesting discussion on water and electrolyte metabolism.
\end{abstract}

Keywords: Gitelman syndrome, hyponatraemia, hypophosphataemia

Singapore Med J 2013; 54(1): e18-e20

\section{INTRODUCTION}

Gitelman syndrome (GS) is one of the most frequently inherited renal tubular disorders. ${ }^{(1)}$ It is an autosomal recessive disorder of the sodium-chloride transport in the thiazide-sensitive sodium chloride cotransporter (NCCT), which is located in the distal tubule. In the majority of the patients, this mutation is found in the SLC12A3 gene on chromosome $16 q 13$ that encodes the thiazide-sensitive NCCT. ${ }^{(2)} \mathrm{GS}$ is characterised by hypokalaemia, hypomagnesaemia, metabolic alkalosis and low urinary calcium excretion. ${ }^{(3)}$ Patients usually present in late childhood or early adolescence. The most important condition to include in the differential diagnoses of GS is Bartter syndrome (BS), an autosomal recessive disorder characterised by a defect in the $\mathrm{Na}-\mathrm{K}-2 \mathrm{Cl}$ / $\mathrm{ROMK} / \mathrm{Cl}$ cotransporter located in the thick ascending limb of the loop of Henle.(2) Hyponatraemia and hypophosphataemia are not recognised features of GS. ${ }^{(3)}$ Here, we present a case of GS that was complicated by severe hyponatraemia and hypophosphataemia. To the best of our knowledge, there has been no published report of this nature.

\section{CASE REPORT}

A 17-year-old boy presented with fever that persisted for one month, cough and chest congestion for ten days, and lethargy for one week. He had a high-grade fever of up to $38^{\circ} \mathrm{C}$, intermittent in nature, and associated with rigors and chills. His fever was relieved by antipyretics and antibiotics prescribed by a family physician. However, the patient continued to feel extremely weak and lethargic. He was admitted with the working diagnosis of chest infection. Table I summarises the results of the laboratory investigations conducted in the patient.
Table I. Results of the laboratory investigations.

\begin{tabular}{|c|c|c|}
\hline Test & Values & Normal range \\
\hline \multicolumn{3}{|l|}{ Complete blood count } \\
\hline WBC $\left(\times 10^{3} / \mu \mathrm{L}\right)$ & 18 & $3.8-9.8$ \\
\hline Haemoglobin $(\mathrm{g} / \mathrm{dL})$ & 15 & $13.8-17.2$ \\
\hline Haematocrit (\%) & 42 & $40.7-50.3$ \\
\hline Platelets $\left(\times 10^{3} / \mu \mathrm{L}\right)$ & 280 & $140-440$ \\
\hline \multicolumn{3}{|l|}{ Serum chemistry ( $\mathrm{mmol} / \mathrm{L})$} \\
\hline Sodium & 115 & $135-145$ \\
\hline Potassium & 1.0 & $3.3-4.9$ \\
\hline Chloride & 87 & $97-110$ \\
\hline Bicarbonate & 16 & $22-31$ \\
\hline Urea & 1.78 & $2.5-6.7$ \\
\hline Creatinine & 88 & $0.06-0.12$ \\
\hline Fasting blood sugar & 6.05 & $4.5-5.6$ \\
\hline Calcium & 2.05 & $2.20-2.67$ \\
\hline Phosphorus & 0.32 & $0.8-1.5$ \\
\hline Magnesium & 0.58 & $0.7-1.1$ \\
\hline \multicolumn{3}{|l|}{ Other investigations } \\
\hline Albumin (g/L) & 31 & $35-50$ \\
\hline Calculated serum osmolality (mOsm/kg) & 237 & $270-290$ \\
\hline Measured serum osmolality (mOsm/kg) & 241 & $270-290$ \\
\hline Urine osmolality (mOsm/kg) & 261 & $80-1350$ \\
\hline TSH (mIU/L) & 5.05 & $0.35-6.20$ \\
\hline Serum cortisol ( $\mu \mathrm{g} / \mathrm{dL})$ & 34 and 54 & $8-25$ \\
\hline \multicolumn{3}{|l|}{ Urine chemistry } \\
\hline Potassium (mmol/L) & 45 & Variable \\
\hline Phosphorus (mmol/24 hr) & $\leq 32$ & Variable \\
\hline Calcium (mmol/24 hr) & 18 & Variable \\
\hline \multicolumn{3}{|l|}{ Arterial blood gas } \\
\hline $\mathrm{pH}$ & 7.56 & $7.35-7.45$ \\
\hline $\mathrm{PCO}_{2}(\mathrm{mmHg})$ & 26 & $35-45$ \\
\hline $\mathrm{PO}_{2}(\mathrm{mmHg})$ & 92 & $80-105$ \\
\hline $\mathrm{HCO}_{3}(\mathrm{mEq} / \mathrm{L})$ & 24 & $22-31$ \\
\hline $\mathrm{O}_{2}$ saturation $(\%)$ & 99 & $90-100$ \\
\hline
\end{tabular}

WBC: white blood cell; TSH: thyroid-stimulating hormone 
The patient was treated with intravenous (IV) potassium chloride, IV magnesium sulfate, IV antibiotics and other supportive measures. His condition improved significantly with the treatment given. On Day 6 of his hospitalisation, he was discharged with the following medications: spironolactone $25 \mathrm{mg}$ three times a day (TID), ramipril 1.25 mg daily, vitamin B complex 1 tablet daily and liquid potassium chloride $30 \mathrm{mEq}$ TID. Table II shows the trends in serum concentrations of potassium and magnesium over the six-day hospitalisation.

\section{DISCUSSION}

The combination of hypokalaemia, hypomagnesaemia and metabolic alkalosis is a common presentation of patients on the medical floor. ${ }^{(2)} \mathrm{GS}$ and Bartter syndrome are always considered in the differential diagnoses of such cases. Our patient fulfilled all of the diagnostic criteria for GS. In addition, the case was complicated by severe hyponatraemia and hypophosphataemia. In the following paragraphs, we will discuss how we reached the diagnosis of GS and the most likely explanations for the hyponatraemia and hypophosphataemia in our patient.

The first step in the workup of hypokalaemia is urine potassium (urine K) measurement. ${ }^{(3)}$ Although 24-hour urine $\mathrm{K}$ measurement is preferable, spot urine $\mathrm{K}$ measurement is also a reasonable and commonly used alternative. ${ }^{(4)}$ The transtubular potassium gradient (TTKG) is another helpful test for diagnosing hypokalaemia. The normal value for TTKG ranges from 4-8. Hypokalaemia is considered secondary to renal loss if urine $\mathrm{K}$ is $>30 \mathrm{mmol} / \mathrm{L}$ or TTKG is high. When urine $\mathrm{K}$ is $<30 \mathrm{mmol} / \mathrm{L}$ or TTKG is low, hypokalaemia may be caused by either an extrarenal loss or a transcellular K shift..$^{(5)}$ In our patient, the spot urine $\mathrm{K}$ concentration was measured twice (first $28 \mathrm{mmol} / \mathrm{L}$; second $45 \mathrm{mmol} / \mathrm{L}$ ). Due to the borderline results, we calculated the TTKG, which was 25:1. This high TTKG value strongly supports renal $\mathrm{K}$ loss as the cause of hypokalaemia. Other important causes of renal $\mathrm{K}$ loss include diuretics, hyperaldosteronism, hypomagnesaemia, renal tubular acidosis types 1 and 2, and certain drugs, e.g. amphotericin and aminoglycosides. ${ }^{(6.7)}$

Arterial blood gas analysis revealed a $\mathrm{pH}$ of 7.56, $\mathrm{PCO}_{2}$ at $3.46 \mathrm{kPa}(26 \mathrm{mmHg})$ and $\mathrm{HCO}_{3}$ at $24 \mathrm{mmol} / \mathrm{L}(24 \mathrm{mEq} / \mathrm{L})$. For $\mathrm{PCO}_{2}$ at $3.46 \mathrm{kPa}(26 \mathrm{mmHg})$, the expected $\mathrm{HCO}_{3}$ concentration would be $21 \mathrm{mmol} / \mathrm{L}(21 \mathrm{mEq} / \mathrm{L})$ in the case of acute respiratory alkalosis and $18 \mathrm{mmol} / \mathrm{L}(18 \mathrm{mEq} / \mathrm{L})$ in the case of chronic respiratory alkalosis. $\mathrm{HCO}_{3}$ at $24 \mathrm{mmol} / \mathrm{L}(24 \mathrm{mEq} / \mathrm{L})$ in our patient indicates mixed metabolic and respiratory alkalosis. ${ }^{(5)}$

Hypokalaemia and metabolic alkalosis are also features of Bartter syndrome. The serum magnesium concentration distinguishes between the two syndromes, being low in GS and normal in Bartter syndrome. ${ }^{(6)}$ However, the key difference between the two syndromes is the level of urinary calcium excretion - low in GS but high in Bartter syndrome. ${ }^{(5)}$ The usually accepted cut-off value is $2.5 \mathrm{mmol}(100 \mathrm{mg})$ of calcium per 24 hours of urine. In our patient, the 24-hour urine calcium measurement was $1.8 \mathrm{mmol}(74 \mathrm{mg}$ )
Table II. Trends in serum potassium, urine potassium and serum magnesium concentrations over the patient's six days of hospitalisation.

\begin{tabular}{lccc}
\hline Day & $\begin{array}{c}\text { Serum potassium } \\
(\mathbf{m m o l} / \mathbf{L})\end{array}$ & $\begin{array}{c}\text { Urine potassium } \\
\mathbf{( m m o l} / \mathbf{L})\end{array}$ & $\begin{array}{c}\text { Serum magnesium } \\
\mathbf{( m m o l} / \mathbf{L})\end{array}$ \\
\hline 1 & 1.00 & 28.00 & 0.58 \\
2 & 3.10 & - & 0.96 \\
3 & 2.40 & 45.00 & 0.65 \\
4 & 2.80 & - & 1.54 \\
5 & 2.60 & - & 0.75 \\
6 & 3.00 & 119.00 & 1.08 \\
\hline
\end{tabular}

per day, which is very low and strongly favours a diagnosis of GS. ${ }^{(7)}$

In summary, the following features were present in our patient and support a diagnosis of GS: an age of 17 years, normal to low blood pressure, hypokalaemia, metabolic alkalosis, hypomagnesaemia, and hypocalciuria. The second significant problem in our patient was the very low serum sodium concentration of $115 \mathrm{mmol} / \mathrm{L}$. Our patient's volume status was normal, as supported by urine sodium concentrations of $41 \mathrm{mmol} / \mathrm{L}$ and $57 \mathrm{mmol} / \mathrm{L}$. The calculated serum osmolality was $237 \mathrm{mOsm} /$ $\mathrm{kg}$ and the measured serum osmolality was $241 \mathrm{mOsm} / \mathrm{kg}$. The osmolar gap was only four. Urine osmolality was $261 \mathrm{mOsm} / \mathrm{kg}$. The blood urea nitrogen, creatinine, thyroid-stimulating hormone (TSH) and cortisol concentrations were all normal. All of these parameters favour a diagnosis of syndrome of inappropriate secretion of antidiuretic hormone (SIADH). ${ }^{\left({ }^{8}\right)}$ However, there are two reservations regarding the use of the urine sodium concentration as supporting evidence for a normal volume status and for a diagnosis of SIADH. First, urine sodium concentration is not a reliable indicator of volume status in patients with metabolic alkalosis, but urine chloride concentration is. ${ }^{\left({ }^{8}\right)}$ In our patient, urine chloride concentration was measured twice, and the values of $59 \mathrm{mmol} / \mathrm{L}$ and $86 \mathrm{mmol} / \mathrm{L}$ support a diagnosis of SIADH. ${ }^{(9)}$

Another point to consider is that hydrochlorothiazide (HCTZ) is a recognised cause of hyponatraemia. As GS is physiologically similar to the use of HCTZ, one may argue that the mechanism of hyponatraemia is similar in both circumstances. The aetiology of thiazide-induced hyponatraemia is multifactorial. It has been suggested that renal sodium wasting, hypovolumia and an intracellular $\mathrm{K}$ deficit play a role in development of hyponatraemia. ${ }^{(10)}$ However, an interesting observation is the impairment of free water excretion by thiazide diuretics, leading to slight volume expansion as a primary event. This, in turn, triggers or aggravates hyponatraemia. A similar phenomenon may be responsible for hyponatraemia in patients with GS, but it is difficult to distinguish from SIADH. ${ }^{(11)}$ Schepkens et al published a case report of two patients with GS that is similar to our patient's case. Both cases were complicated by severe hyponatraemia and hypouricaemia. The first patient with a serum sodium concentration of $119 \mathrm{mmol} / \mathrm{L}$ presented with SIADH-like biochemical features. The second patient with a serum sodium concentration of 
$116 \mathrm{mmol} / \mathrm{L}$ presented with mixed features of volume depletion and SIADH. ${ }^{(10,11)}$

The third problem noted in our patient was severe hypophosphataemia. Again, the initial key test is the measurement of urinary phosphorus in any case of hypophosphataemia. Urinary phosphorus $>3.2 \mathrm{mmol}(100 \mathrm{mg}) /$ day indicates renal loss, while a level $<3.2 \mathrm{mmol}(100 \mathrm{mg}) /$ day indicates either nonrenal loss or a transcellular shift. ${ }^{(12)}$ In our patient, urine phosphorus concentration was very low at $1.0 \mathrm{mmol} / \mathrm{L}(3.1 \mathrm{mg} / \mathrm{dL})$ and $1.49 \mathrm{mmol} / \mathrm{L}$ $(4.6 \mathrm{mg} / \mathrm{dL})$ at two different measurements. The estimated 24-hour urinary phosphorus was very much less than $32 \mathrm{mmol}$ (100 mg)/day. This extremely low urine phosphorus concentration ruled out renal loss as a cause of the hypophosphataemia. In addition, there was no gastrointestinal loss. Thus, the most likely explanation for the hypophosphataemia in our patient was a shift of phosphorus from the extracellular compartment to the intracellular compartment. Respiratory alkalosis is an important and known cause of such a cellular shift, ${ }^{(13)}$ and this was present in our patient. Thus, we concluded that respiratory alkalosis was the most likely explanation of hypophosphataemia in our patient. In the literature, there are only two case reports of severe hypophosphatemia in patients with GS. In Akhtar et al's report of a patient with GS and hypophosphataemia, no clear-cut aetiology of hypophosphataemia was identified. ${ }^{(14)}$ On the other hand, increased urinary phosphate excretion was the suggested mechanism of hypophosphataemia in Katopodis et al's report. ${ }^{(15)}$

In conclusion, GS was the final diagnosis in our patient. It was associated with severe hyponatraemia and hypophosphataemia. Hyponatraemia was most likely secondary to SIADH, and hypophosphataemia secondary to respiratory alkalosis. We feel that this case report would contribute to the literature by generating an interesting discussion of renal physiology in relation to water and electrolyte metabolism.

\section{REFERENCES}

1. Gladziwa U, Schwarz R, Gitter AH, et al. Chronic hypokalemia in adults: Gitelman's syndrome is frequent but classical Bartter's syndrome is rare. Nephrol Dial Transplant 1995; 10:1607-13.

2. Roser M, Eibl N, Eisenhaber B, et al. Gitelman Syndrome. Hypertension 2009; 53:893-7.

3. Jang HR, Lee JW, Oh YK, et al. From bench to beside: diagnosis of Gitelman's syndrome - defect of sodium chloride cotransporter in renal tissue. Kidney Int 2006; 70:813-7.

4. Rose BD. Meaning of urine electrolytes In: Rose BD, ed. Pathophysiology of Renal Disease. 5th ed. New York: McGraw-Hill, 2001.

5. Koch MJ. Disorders of Potassium Balance. In: Windus D, Henderson KE, De Fer TM. Nephrology Subspecialty Consult. 2nd ed Philadelphia: Lippincott Williams \& Wilkins, 2008.

6. Knoers NV, Lertchenko EN. Gitelman syndrome. Orphanet J Rare Dis 2008; $3: 22$.

7. Greenlee M, Wingo SC, Mc Donough AA, Youn JH, Kone BC. Narrative Review: evolving concepts in potassium homeostasis and hypokalemia. Ann Intern Med 2009; 150:619-25.

8. Schrier R. Renal and Electrolyte Disorders, 6th ed. Philadelphia: Lippincott Williams \& Wilkins, 2003: 109-15.

9. Sherman RA, Eisinger RP. The use (and misuse) of urinary sodium and chloride measurements. JAMA 1982; 247:3121-4.

10. Mann SJ. The silent epidemic of thiazide-induced hyponatremia. J Clin Hypertens (Greenwich) 2008; 10:477-84.

11. Schepkens H, Stubbe J, Hoeben H, Vanholder R, Lameire N. Severe hyponatraemia and hypouricaemia in Gitelman's syndrome. Nephrol Dial Transplant 2001; 16:2250-2.

12. Halevy J, Bulvik S. Severe hypophosphatemia in hospitalized patient. Arch Intern Med 1988; 148:153-5.

13. Mostellar ME, Tuttle EP Jr. Effects of alkalosis on plasma concentration and urinary excretion of inorganic phosphorus in man. J Clin Invest 1964; 43:138-49.

14. Akhtar N, Hafeez F. A rare case of Gitelman's syndrome with hypophosphatemia. J Coll Physicians Surg Pak 2009; 19:257-9.

15. Katopodis K, Elisaf M, Siamopoulos KC. Hypophosphataemia in a patient with Gitelman's Syndrome. Nephrol Dial Transplant 1996; 11:2090-2. 